\section{The Excellence Baldrige Criteria in The Effectiveness of Higher Education Institutions Management}

\author{
Paulo Henrique Barroso Menezes ${ }^{\dagger}$ \\ Universidade FUMEC \\ Henrique Cordeiro Martins ${ }^{\Omega}$ \\ Universidade FUMEC \\ Ronielton Rezende Oliveira ${ }^{¥}$ \\ Universidade FUMEC
}

\section{ABSTRACT}

This paper aims to analyze the antecedents of effectiveness of education management in seven units of a Higher Education Institution (IES, in Portuguese) located in the metropolitan region of Belo Horizonte, MG, Brazil. The research is a quantitative study and was applied in the case study format in the largest private Brazilian education organization listed in the stock market. Data sample were collected through a survey and the informants are directors, course coordinators, teachers and administrative staff. The results were obtained through the structural equation modeling in relation to Excellence Baldrige Criteria, and indicate the model proposed by this research, that the Strategic Planning and Operation Focus influence directly on the Effectiveness of Management. We verified the existence of a positive correlation between all the constructs of the Baldrige Excellence Model with the Effectiveness of Management of the HEI.

Keywords: Education; Effectiveness of management; Higher education institution; Baldrige excellence model.

\section{INTRODUCTION}

In Brazil, starting from the economic opening of the nineties, a great milestone was discussed on the challenges of Brazilian organizations, mainly due to the lack of qualification of the workforce and the lack of schooling of the population. Thus, the United Nations Educational, Scientific and Cultural Organization (UNESCO) and the World Bank have favored the increase in Brazilian higher education, through private initiative. This activity has been controlled by the public power, since the Constitution of the Federative Republic of Brazil establishes, as a prerogative of the State, authorize the operation of the Private Higher Education Institution (HEI), according to the Magna Carta in its Article 209, subsections I and II (BRAZIL, 1988). Thus, the Law 9.394/1996 (Law of Guidelines and Bases - LDB) and Law 10.172/2001 (National Education Plan - PNE) expanded access to higher education (SILVA JÚNIOR, MUNIZ and MARTINS, 2009). Therefore, in some ways the practices and management models adopted by private HEIs are influenced by the state framework and public policies, stemming from the current legislation.

Data from the Census of Higher Education (INEP, 2014) show that $87.42 \%$ of the country's HEIs are private. Brazilian HEIs have been

\author{
Corresponding author: \\ †Universidade FUMEC \\ E-mail: paulohbm.economia@gmail.com \\ ${ }^{\Omega}$ Universidade FUMEC \\ E-mail: henrique.martins@fumec.br \\ ${ }^{¥}$ Universidade FUMEC \\ E-mail: ronielton@fumec.edu.br \\ Received: 07/13/2016. \\ Revised: 08/07/2016. \\ Accepted: 10/20/2016. \\ Published Online: 11/01/2017.
}


undergoing several environmental changes. The increase in the number of vacancies in different institutions has demonstrated the constant need to adapt the HEI management models, mainly due to the scenario of wide competition and the creation of large investment groups, as is the case, of the merger, for example, between Kroton Educational and Anhanguera Educational, on April 22, 2013. In the same year, on September 12, 2013, the purchase of the University Center UniSEB by Estácio de Sá also took place. And more recently, the announcement, on July 1, 2016, of the merger between Estácio de Sá and Kroton Educacional, in an operation estimated at more than 5 billion (BRL) and that will result, after approval by the Administrative Council of Economic Defense (CADE), in a giant of more than 1.6 million students.

With this new scenario, it is fundamental for the private education market to obtain organizational results of sustainability and excellence, seeking, in the management model, transparency for shareholders and stakeholders. Education companies should consider their own performance in the stock market, via the Stock Exchange of the State of São Paulo (BOVESPA), in accordance with the rules of the Brazilian Securities and Exchange Commission (CVM), for the required governance level with the intention of maintaining the attractiveness of investors. Considering these transformations, Brazilian HEIs then need to use management tools in their strategies, so that the elements of success that lead to results are predicted, according to the mission, vision and institutional values, and also seek financial results that mean benefits for shareholders, in addition to the qualitative results required by the Ministry of Education (MEC).

In the United States of America (USA), private educational institutions have a program of excellence in education termed as Malcolm Baldrige National Quality (BNQP), that developed the Baldrige Excellence Model. This quality program seeks, through partnerships between the public and private sectors, to determine a guide of good management practices in educational institutions capable of leading to results that aim not only to improve educational quality but also to promote innovation, competitiveness and scientific advances, increasing the quality of national enterprises and competitiveness (BPEP, 2011).

In Brazil, there is no initiative in this sense, public or private. What we can verify is the existence of punctual actions to improve national competitiveness, through bodies such as the Federation of Industries and the Federation of Commerce, for their respective publics. Thus, in view of the challenges of Brazilian HEIs, and considering that information and strategy management has been making efforts to use effective management tools, with the objective of achieving organizational returns with benefits to society and competitiveness (MAINARDES, MIRANDA e CORREIA, 2011), this study seeks to answer the following question: What are the antecedents of the Effectiveness of Management of Higher Education Institutions in Brazil, based on the elements highlighted in the Baldrige Excellence Model? By these means, the objective of this study is to analyze the effectiveness of management of higher education of a Brazilian HEI in accordance with the Baldrige Excellence Model.

The Baldrige Excellence Model was chosen and used in this research because it seeks to respond to the need for HEIs by combining innovation and national development results, through good practices adopted within management, according to the strategies of the investment groups. And as a consequence, to promote the overall improvement of national enterprises, competitiveness, education and financial results for investors (BPEP, 2011). In addition, the Baldrige Excellence Model is adequate to the reality of Brazilian HEIs, as shown in the study by Galvão, Corrêa and Alves (2011), which proposed a "Global Performance Evaluation Model for HEI". In this study, the BNQP principles were also adopted as one of the points of support to present the "dimensions and elements of the proposed model" (p. 435), whose focus falls on the requirements of the MEC and is adherent to the context of Brazilian education. 
BBR

15,1

49

It is understood that this study is important in Brazil. Firstly, because it is an issue related to the institutional evaluation in the HEI. In addition, it manages to capture the institutional movement present in the institution's relations and contribute to the process of improvement and management practices (BRANDALISE, 2010). Second, because the Brazilian educational market undergoes significant transformations due to the increase of higher education institutions that have shares in the stock exchange, and this flow of information results in environmental changes in HEIs which, in turn, implies the constant adaptation of HEI management models, mainly due to the scenario of wide competition and the creation of large investment groups, the opening of new institutions and the offer of new places for higher education (MAINARDES, MIRANDA e CORREIA, 2011).

In addition, educational management (SOUZA and BEZERRA, 2004; BARBOSA, MENDONÇA and CASSUNDE, 2015; DONINA and BRUCKMANN, 2015; FREITAS JÚNIOR et al., 2015) on the fundamentals of governance (CLAUDIA, VEIGA and AMARAL, 2013; MAGALHÃES et al., 2013; SARRICO, VEIGA and AMARAL, 2013) given the strategic leadership in educational institutions (MAGALHÃES and VEIGA, 2014), focusing on results (MORALES and MAGALHÃES, 2013), on aspects of efficiency and effectiveness (BERTUCCI and DE MORAES, 2003; DARAIO, 2015) is a topic widely discussed by national and international research in the perspective of strategic planning (VIDIGAL and CAMPOS, 2015), performance mechanisms, evaluation mechanisms (HALLIGAN, SARRICO and RHODES, 2012; TELLES and MARINHO, 2013; PAIVA et al., 2014; ZANIN et al., 2014; PALMEIRAS, SGARI and SZILAGYI, 2015) and measurement of educational processes (ROSA, SANTOS and SANTOS, 2006; BRUCKMANN and CARVALHO, 2014).

For this reason, the creation of new companies in the educational field with mergers and acquisitions amplifies the importance of the unit of study, since, with the last facts that took place, we note in the private HEI model in Brazil a focus on profitability. This movement gives relevance to the management of HEI and its effectiveness, because what is wanted is to understand the everyday applications and the influences that perhaps are perceived in the transformation of labor and innovation with the improvement of the quality of education. In this sense, the research contributes to the scenario of predominance of private HEIs, according to the goals established by Brazilian legislation (SILVAJÚNIOR, MUNIZ and MARTINS, 2009), and also with the changes in the competitive environment of HEIs (MAINARDES, MIRANDA and CORREIA, 2011), we seek to understand the correlation of the effectiveness of the management of Brazilian HEIs, based on the Baldrige Excellence Model, since, according to this model, a country's progress and the development of technology are directly associated with the efficient management of educational institutions (BPEP, 2011).

The article is organized in five parts, besides this introduction. The second part presents a review of the literature on the Criteria of Excellence Baldrige and Effectiveness, that is, the constructs that support the hypothetical model. In the third section, the study is classified as the methodology, the case study is described, the data of the sample as well as the use of the factorial analysis. In the fourth section, supported by the structural equation modeling, the models are presented, first, the hypothetical one, which was partially supported by the research, and then the alternative model, which confirmed the correlation between the constructs in the scenario of Brazilian HEIs. In addition, we perform the analyses resulting from the hypotheses evaluation about the models. Finally, in the fifth part, final considerations, observations on the study, limitations and suggestions for future research are presented. 


\section{EXCELLENCE BALDRIGE CRITERIA AND EFFECTIVENESS}

The Malcolm Baldrige National Quality Award (USA) is the result of a publicprivate partnership whose main objective is to encourage competitiveness. To this end, the Department of Commerce, a body linked to the National Institute of Standards and Technology (NIST), promotes an award for universities, industries and research consortia in potentially revolutionary technologies. The program seeks to contribute to the improvement of products, technologies and patents, with the assistance of the American Quality Society (AQS). The Malcom Foundation is the fundraising body in the American society for cash prizes to be shared among the winners, evaluated according to the NIST criteria, together with the AQS (BPEP, 2011). In dealing specifically with educational institutions, Figure 1 represents the quality and management criteria that should be defined according to each organization being evaluated, with it being possible to adapt the model to universities, industries, research consortia, among others.

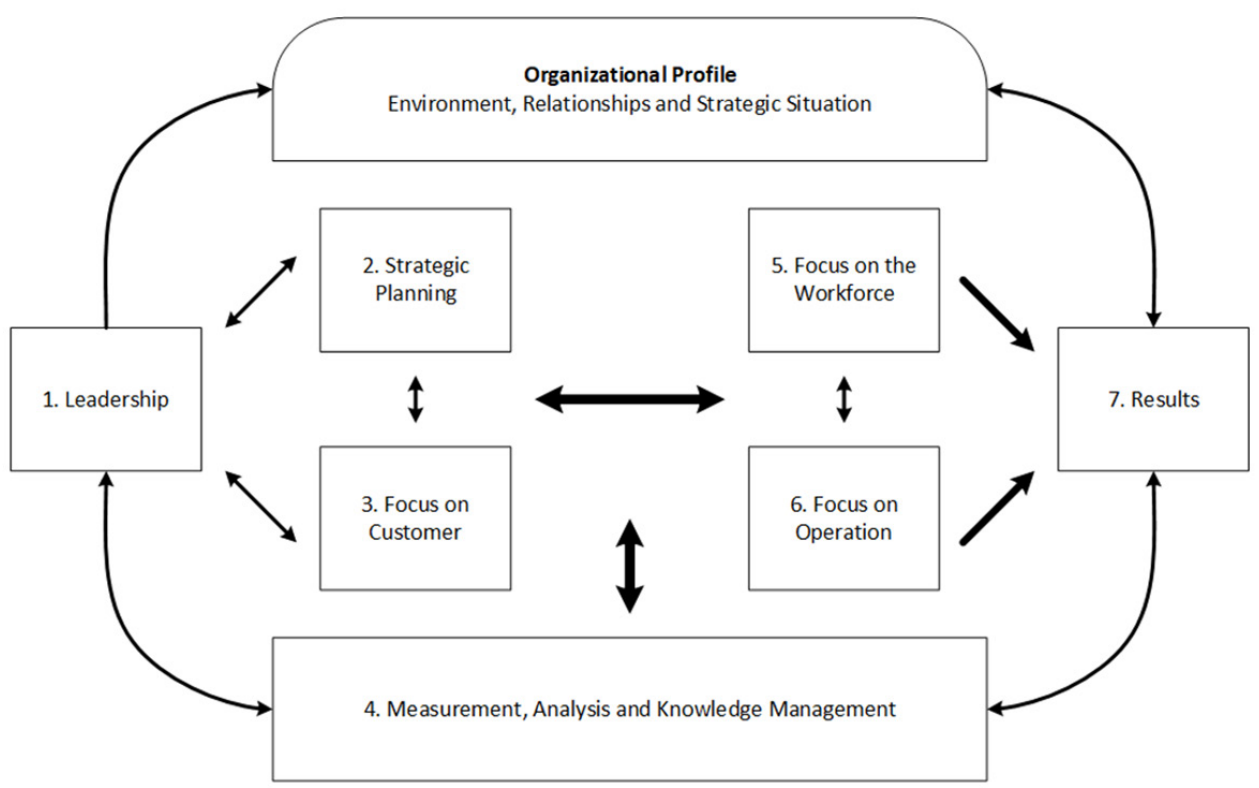

Figure 1. Baldrige Excellence Model

Source: Adapted from Criteria for Performance Excellence (BPEP, 2011).

The Baldrige Excellence Model perspective places the organization within the environmental context, that is, it seeks to identify the elements considered when formulating the strategy: regulatory mark, number of competitors, type of strategy adopted and the market in which it competes. The Organizational Profile serves as a general guide for organizational performance to determine the climate of the internal relationships with students, partners, suppliers and stakeholders (BPEP, 2011). According to Barreto and Pozo (2011, p. 99), "the external environment, such as market and competitiveness, contributes to the structural evolution of the companies", there are also internal environments analyzes, in order to make processes better and more efficient. The need to analyze the entire organizational environment requires an accurate perception of the organizational profile, with the understanding of the internal and external environments, enabling that the planning stage to be adequate to all the needs and that its implementation takes place successfully. This is one of the main pillars of the Baldrige Excellence Model, considering that, from the organizational profile, it is possible to determine the other interactions of the seven criteria for the search of the result. Therefore, the perception of the organizational profile means to classify the organization itself in relation to its deliberate strategy (BPEP, 2011), that is, 
BBR

15,1

51

what are the statements of its mission, vision, values and the paths by which it is sought to reach the strategic objectives.

Leadership can be defined as "a process of influencing the activities of a group towards the achievement of its objectives, through an interaction between two or more people who, often, involved in the construction or deconstruction of situations, perceptions and expectations" (SOBRAL and GIMBA, 2012, p. 99). The criterion of Leadership seeks to evaluate the actions of organizational leaders and the perception of these actions in order to achieve the strategic goals of the organization (BPEP, 2011). The objective of the leader expected by the model is then compatible with that suggested by Rocha, Cavalcanti and Souza (2010, p. 36), since "leading corresponds to a process of intentionally influencing an individual in order to achieve a goal". This represents a consensus in the literature, according to these authors, by pointing out that current approaches to leadership need to take into account the behavior of the leader over their subordinates and should also assess the complex set of variables involved in the environment in which leadership is exercised by abandoning the classical idea of leadership, in which one assumes that the groups are basically similar, at least in relation to the role of the leader (ROCHA, CAVALCANTE and SOUZA, 2010).

We hope, therefore, that organizational leaderships have the competencies to guide and sustain their leaders within the ethical and legal limits and that are capable of maintaining the statements of the organization's mission, vision and values, in addition to evaluating whether the actions and how to communicate are contributing for the objectives to be achieved. In this sense, leadership must be able to establish a two-way communication channel, effectively communicating important decisions, assuming an active role, in order to reinforce the ethical, professional and interested behavior of the work teams and also of the students. Thus, the leaderships described in the Baldrige Excellence Criteria are in harmony with the studies that present the description of an authentic leadership (SOBRAL and GIMBA, 2012; ROCHA, CAVALCANTE and SOUZA, 2010). This must be verified by means of the hypothesis 1 :

H1: Leadership positively influences the HEI's Management Effectiveness.

The strategic planning process is defined as an organizational tool for support and decision-making (KICH and PEREIRA, 2011). The analysis of the Strategic Planning, within the Excellence Baldrige Criteria, is considered on the development of the HEI strategic planning and action plan. For this purpose, the plans are evaluated, as a central element, and also the control of the goals and adaptations to the changes of environment is made, thus measuring, the ability to adapt to environmental changes, included in the strategic plan (BPEP, 2011). The step of converting the strategic plan into a plan of action draws special attention in the program, since the other elements are fundamentally important. For example, leadership and leadership communication about planned strategies, goals and actions, which is why there is a link between leadership and strategy. Souza (2011) evolution of the strategy in organizations, and the initial studies demonstrate the definition of the content of the strategy in which one seeks the understanding of what is necessary to draw up a strategy. The evolution of the initial idea is the resource-based view, an assumption in which an approximation between the strategy and the organization is possible, with the intent of gaining competitive advantages. Finally, the procedural approach points to the strategic objective that is in the direction of focus, for the analysis of the daily formation of the strategy (WHEATON et al., 1997; KICH and PEREIRA, 2011; SOUZA 2011). This should be verified through hypothesis 2 :

H2: O Strategic Planning positively influences of the HEI's Management Effectiveness.

The focus on the client is defined by the pursuit of quality and satisfaction, promoting changes on planning, aiming at specific objectives (BARRETO and POZO, 2011). The authors use the assumption that clients are sensitive to quality, which is why management 
must be flexible, in order to take into account, in its strategy, the aspect that enables the focus on customer. Connected to leadership and also to strategy, the Focus on Customer dimension, within the Baldrige Excellence Criteria, seeks to identify how the organization will capture the information in its student body, and how the segmentation of the students will be done so that the demands are understood within different groups of students. Special attention is given to the way in which alumni are heard and also the future students of the institution (BPEP, 2011). In addition, the focus on customer needs criteria on how the behavior of the students' level of satisfaction with competitors is, and indicators of comparison with the competition, regarding the level of satisfaction. Special attention is given to the level of dissatisfaction of all clients and potential customers, even in a way compared to competitors (BPEP, 2011; BARRETO and POZO, 2011). This should be verified through hypothesis 3 :

H3: Focus on Customer positively influences the HEI's Management Effectiveness.

The criterion of Measurement, Analysis and Knowledge Management becomes the basis of the model, since it is the main tool that will provide the element of information collection and analysis, to generate better organizational results. Its correlation with leadership, with the client, with the strategy, with the operation and, as a consequence, with the result, is significant, in the same way as with the organizational profile, directly affecting the way of collecting and storing the data (BPEP, 2011). Part of the objective of this criterion is to organize an information system capable of supporting prediction of problems and decision making, which was defined by Georges $(2010$, p. 640) as "a group of elements organized for the purpose of supporting operational management and decision making", or even as a "set of interconnected components, which collects, processes, stores and distributes information to support decision-making and to control the organization". Fidelis and Barbosa (2012) demonstrate the importance of informational competence for the understanding of competitive scenarios and understanding of the business environment, enabling the change of strategy. The main tool that the manager will have at their disposal is the information, with it being crucial, for the success of the result, the use in the correct way and to be able to generate improvements in the performance. It should be stressed, therefore, that information has become a primordial resource for the development of organizations of any nature (GEORGES, 2010; FIDELIS and BARBOSA, 2012). This should be verified through hypothesis 4:

H4: Measurement, Analysis and Knowledge Management positively influence the HEI's Management Effectiveness.

Focus on the Workforce is a criterion that relates to the others within the model, since most of the team will work directly in contact with the student to apply the HEI's strategic planning. Therefore, we look for measures on how to create a suitable working environment in order to create high performance teams and how these results will directly influence outcomes (BPEP, 2011). The control of the decision-making process and the decentralization of autonomy can also be analyzed from the perspective of the focus on the work force, the stimulus in participation and the increase of commitment as the actions that keep it in tune, a role that is highly determined by the performance and connection with the leadership. Barreto and Pozo (2011) define this step as that which presupposes the leader-led analysis. The management of work teams aims to achieve punctual results to accomplish the plan of action outlined, with a view to exceeding customer expectations and addressing strategic challenges. The aim is to achieve these objectives, together with tools for measuring, analyzing and managing knowledge. In this sense, it is necessary to prepare the workforce for the long-term challenges of the organization, which includes training (BPEP, 2011; BARRETO and POZO, 2011). This should be verified through hypothesis 5:

H5: Focus on the Workforce positively influences the HEI's Management Effectiveness. 
BBR

15,1

53

According to Barreto and Pozo (2011), the stage of work organization promotes the integration of the teams and the global vision of the activities, facilitating the process of changes, besides privileging the organizational objectives to the detriment of objectives by sector. The Focus on Operation is about the strategy in action, that is, the possible ways in which the organization will operationalize the strategy as a way to respond to the daily demands in pursuit of the objectives outlined. This criterion of the model, besides analyzing the organization of the current processes of work and management of educational projects, seeks to innovate existing processes in favor of improvements with forecast contingency and risk analysis; with this, it intends to achieve the success of the current operations and sustainability, and the readiness to contour emergencies (BPEP, 2011). The process of implementing strategic planning, through daily operations, requires that managers develop strategies gradually (KICH and PEREIRA, 2011). Thus the use of the organization's experience also implies respect for the existing regional issues. Thus, "emerging strategies are those that emerge during the implementation of strategic planning, that is, strategies that were not developed in advance" (KICH and PEREIRA, 2011, p. 1049). In the case of this study, emerging strategies are necessary, especially when it comes to studying a Brazilian HEI (BARRETO and POZO, 2011; KICH and PEREIRA, 2011). This should be verified by means of hypothesis 6 :

H6: Focus on Operations positively influences the HEI's Management Effectiveness.

The criterion Results is based on the comparison of the organization with its direct competitors and also with the goals of reaching its objectives outlined. For this, the model seeks to separate the results in all key areas, according to the above criteria. Thus, the results need to be measured in relation to the students, within the educational model developed, with a focus on the workforce and standard of workforce development, budgeting, financial aspects and market performance (BPEP, 2011). Within each results area, clear indicators of the organization are sought to articulate with the other criteria of the Baldrige Excellence Model.

Thus, the results depend directly on all the effects and indicators achieved by the antecedent criteria, the plans and the profile of the organization as well as the correct use of the data collected, controlled and organized. The perception of results is the implementation of the strategy and its indicators, with a monitoring of the goals (SOUZA, 2011). This understanding is compatible with the propositions of the model, provided that decisions and monitoring are made in the context of the economic and environmental issues surrounding the organization, and to promote convergence between the strategy and its implementation. Souza (2011) points out that it is necessary not only a quantitative analysis of the indicators outlined by the strategy but also an approximation of environmental issues and an analysis with the competition scenarios, in which context the organization is inserted.

Effectiveness is a complex construct within the theory of organizations and involves diverse approaches (BERTUCCI and DE MORAES, 2003), being an "indicator that shows how organizations relate to their environment" (FERNANDES et al., 2007, p.88). In the context of the HEI, the student's satisfaction with teaching should be evaluated; the academic development of the student; career development; personal development; the satisfaction of teachers and employees with their work; professional development and quality of teachers; the opening of the system for interactions with the community; the ability to acquire resources; organizational vitality (CAMERON, 1978), considering the dimensions and the way in which the institutions adapt to the community and the environment in general; to its ability to meet the expectations of its internal constituents and the quality of processes within it; their performance in traditional academic activities, and also their demonstrated ability to acquire scarce resources that are fundamental for the accomplishment of these activities; and extracurricular activities developed by the institution (CAMERON, 1981). 
When analyzing the effectiveness of social programs of access to higher education in Brazil, Saraiva and Nunes (2011, p. 949) demonstrate "the importance of discussing the evaluation of the decision-making process, and, mainly, the measurement of results and impacts of social policies and programs, since the effects have repercussions throughout society". Melo and Neto (2009), in the analysis of the elements of effectiveness in public management, indicate that the definitions of effectiveness, efficiency and effectiveness contribute to the understanding of different steps in the measurement, control and analysis of the strategy. In their view, the indicators reach established goals and products. These are measures that determine effectiveness in relation to a strategic planning program, whereas, for the achievement of intermediate objectives, the implementation of the action plan takes place, both determinants for efficiency measurements.

Thus, effectiveness is a qualitative measure generated from the comparison of the results achieved and accomplished, with those objectives intended and planned. Therefore, the difference between effectiveness and efficacy occurs to the extent that effectiveness consists in the attainment of quantitatively established goals (that is, the effects) over what is planned. The effectiveness is given in the quantitative aspect and, mainly, in the qualitative aspect (that is, the influences), in the relationships between the planned and the final results obtained (MELO and NETO, 2009). The purpose of this study is to indicate the degree to which each element of the Baldrige Excellence Model is relevant to the effectiveness of the Brazilian HEI results, with reference to governance and good management practices (CAMERON, 1978 and 1981; WHEATON et al., 1997; BERTUCCI and DE MORAES, 2003; MELO and NETO, 2009; GEORGES, 2010; ROCHA, CAVALCANTE and SOUZA, 2010; BPEP, 2011; BARRETO and POZO, 2011; KICH and PEREIRA, 2011; SARAIVA and NUNES, 2011; SOUZA, 2011; FIDELIS and BARBOSA, 2012; SOBRAL and GIMBA, 2012). Therefore, we will verify hypothesis 7 :

H7: There is a correlation between the constructs of the model and the HEI's Management Effectiveness.

The Baldrige Excellence Model takes into account that the Baldrige Excellence Criteria are distributed into seven categories and should be analyzed separately (BPEP, 2011). The operational proposition of implementing the model for this research, based on the assumptions of Leadership; Strategic planning; Focus on Customer; Measurement, Analysis and Knowledge Management; Focus on the Workforce; and Focus on Operation, is shown in Figure 2. In this one, the model represents the hypotheses that consider the observation of the categories as constructs that are assumed to have a positive influence on the Results, that is, in the HEI's Management Effectiveness construct.

Finally, the "institutional evaluation is a process of search of the educational reality, with its tendencies, its knowledge, its conflicts and dilemmas" (BRANDALISE, 2010, p. 322). Performance evaluation is an organized process for collecting data on specific criteria, to form opinion based on data and evidence. "Evaluating and measuring performance aims to provide a form of management that is effective for the organization, considering a series of variables such as: principles adopted, information bases and indicators considered. Constantly, the performance evaluation is influenced by the objectives, goals and legislation that influence the educational institution" (TELLES and MARINHO, 2013, p. 2). In the case of HEIs, in order to make an assessment it is necessary to know the elements that configure its structure, the curricular guidelines adopted, the current action plans, among other peculiarities that characterize them as a complex organizational type, because there are particularities and differentials in each educational institution (ZANIN et al., 2014). In this way, the performance evaluation, which includes the institutional evaluation, is understood as a process that offers the educational manager several information which makes it possible to evaluate and measure the effectiveness of the HEI management 
BBR

15,1

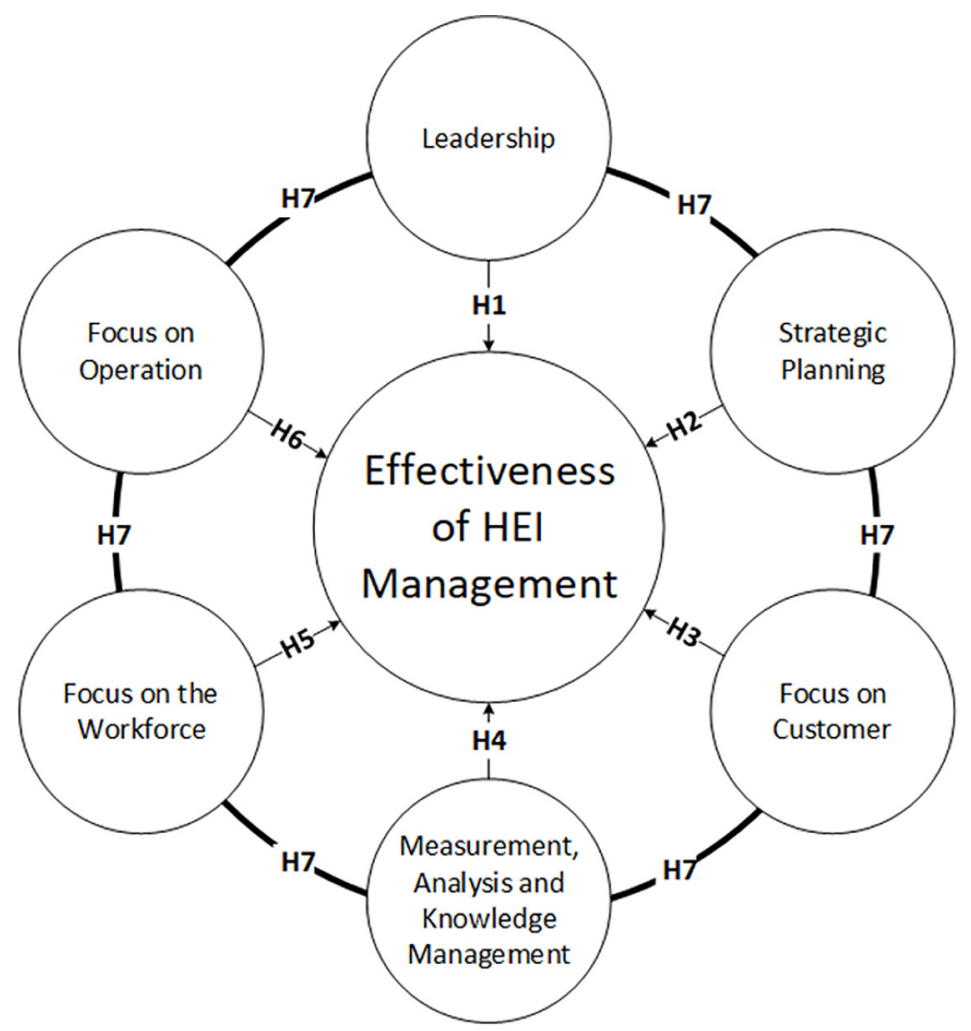

Figure 2. Hypothetical Model.

Source: Elaborated by the authors.

and, with this, to understand the impact of their decisions to implement organizational improvement actions.

\section{METHODOLOGY}

Research of quantitative nature, of the descriptive type in a case study, has as its analysis object the largest private Brazilian for-profit education organization, which operates in the model of investment group in corporation, with participation in the stock exchange. The company has been active in the educational market since 1966, with approximately 411,000 undergraduate and graduate students, with 447 poles of Distance Education (DE) and with 53 campuses of face-to-face teaching located in all regions of the Country. The disclosure of relevant facts to investors by the HEI is that the company, after its last merger in 2014, has an estimated market value of more than 22 billion (BRL) and holds almost one million students in Higher Education in Brazil.

The HEI studied is located in the metropolitan area of Belo Horizonte, MG, Brazil. The informants in the survey consist of Unit Officers, Administrative Employees (Administration, 229 employees), Lectures and Course Coordinators (Faculty, 1,102 employees). The population of 1,331 employees is distributed among the seven units of HEI (Barreiro, Betim, Cidade Jardim, Contagem, Raja Gabaglia, Timbiras and Venda Nova). The research instrument questions were elaborated based on the Baldrige Excellence Model (BPEP, 2011) supported by the theoretical framework. The pre-test of the research instrument was carried out with 5 employees of the HEI and no inconsistencies were detected. The Likert scale questionnaire ranging from one to ten was composed of 46 questions required as mandatory, so that, in no answered questionnaire, there were missing data. The research instrument is presented in Table 1. 
Table 1. Research instrument.

Leadership

II.1 The actions of my leaders serve as examples and inspiration.

II.2 My leadership has actions corresponding to the Organization's Mission, Vision and Values.

II.3 Leadership communicates effectively with everyone in the institution.

II.4 Leadership actions reinforce an ethical commitment and respect for the law.

II.5 Leaders are concerned about the formation of new leaders.

II.6 There are incentives for communication to be honest and direct.

Strategic Planning

III.1 I know the Organization's Mission, Vision and Values.

III.2 All are involved to identify problems and solutions for the organization.

III.3 I know exactly what is expected of me within the organization.

III.4 All the resources I need to perform my tasks are available.

III.5 I know the strategic differentials of the organization.

III.6 The organization can perceive and take advantage of the opportunities of innovation in educational services.

III.7 The organization is able to adapt to sudden changes in scenarios.

Focus on Customer

IV.1 The system for picking up complaints, suggestions, criticisms and compliments provides quick action on problems.

IV.2 Students are involved in solving identified problems.

IV.3 Conducting the relationship with students provides loyalty and a long-term relationship.

IV.4 The relationship with students allows identifying new needs and offering new services.

IV.5 The organization is able to anticipate problems and solve them.

IV.6 The Organization has attractive incentive programs to acquire new students through nominations.

Measurement, analysis and knowledge management

V.1 The model of data collection, selection and alignment happens frequently and safely.

V.2 I rely on data measured and provided by the institution.

V.3 The institution makes it possible to exchange knowledge among all people.

V.4 Information is used to support decision-making.

V.5 The information collected supports service innovation.

V.6 The collected data are compared with the objectives of the organization's strategy.

Focus on the Workforce

VI.1 The activities I develop are in accordance with the skills I possess.

VI.2 The recruitment, selection and remuneration system is compatible with the rest of the market.

VI.3 I get feedback on my performance and achievement of expected goals.

VI.4 Each employee is certified for the role they play in the organization.

VI.5 There are training programs and information on new challenges.

VI.6 The number of people is adequate to the amount of work.

VI.7 The workforce is involved with the organization.

VI.8 The turnover level of professionals is low.

VI.9 I get financial returns when I reach milestones.

Focus on Operation

VII.1 I have the freedom to suggest changes in the way I perform my tasks.

VII.2 Work processes are constantly changing so that they are effectively improved. 
BBR

15,1

VII.3 I know the productivity measure and can suggest the best adaptation and evolution of these measures.

VII.4 Processes are designed to avoid rework and reduce costs, minimizing the possibility of errors.

VII.5 There is planning so that in case of emergency operations continue to run.

VII.6 There is a strict supplier control process.

Management Effectiveness

VIII.1 There is a follow-up program for student learning outcomes.

VIII.2 The results of learning follow-up are better than those of the main competitors.

VIII.3 The student is satisfied with the institution in which he/she studies.

VIII.4 The workforce is satisfied and meets the established goals.

VIII.5 Leadership can implement mission statements, vision and values.

VIII.6 Financial results are higher than investors' expectations.

Source: Research data.

We obtained data by means of a survey with dissemination of the questionnaire on the internet and subsequent sending of an invitation to participate in the research by e-mail. After completing the field survey, we obtained 176 questionnaires, corresponding to $13.22 \%$ of the population. In relation to the demographics of the data, we are aware that this is constituted, mainly, by Professors (79\%), who work in the Bachelor's degree courses (55.6\%), Bachelor and Technologist (20.9\%), Technologist (10.7\%), Bachelor and Postgraduate studies $(2.6 \%)$, Postgraduate studies $(2.0 \%)$ and all previous arrangements $(8.2 \%)$. In relation to the other functions performed at the HEI, $4 \%$ are Course Coordinators, $16 \%$ are Administrative Employees and 1\% of them are Unit Directors. All seven HEI units are represented in the sample, with those being Betim $(31.1 \%)$, Cidade Jardim $(21.9 \%)$, Raja Gabaglia (12.8\%), Timbiras (10.7\%), Barreiro (9.2\%), Contagem (8.2\%) and Venda Nova $(6.1 \%)$. The distribution of respondents by unit and function is shown in Table 2 .

Table 2. Distribution of respondents by unit and function

\begin{tabular}{|c|c|c|c|c|c|}
\hline \multirow[b]{2}{*}{ HEI Unit } & \multicolumn{2}{|c|}{ Administration } & \multicolumn{2}{|c|}{ Faculty } & \multirow[b]{2}{*}{ Total } \\
\hline & $\begin{array}{l}\text { Administrative } \\
\text { Function }\end{array}$ & Unit Director & Professor & Course coordinator & \\
\hline Barreiro & 1 & - & 5 & - & 6 \\
\hline Betim & 24 & - & 9 & 4 & 37 \\
\hline Cidade Jardim & 11 & 1 & 9 & 2 & 23 \\
\hline Contagem & 1 & - & 10 & 1 & 12 \\
\hline Raja Gabaglia & 11 & - & 10 & 1 & 22 \\
\hline Timbiras & 19 & - & 3 & 4 & 26 \\
\hline Venda Nova & 13 & 1 & 32 & 4 & 50 \\
\hline Total per Group & \multicolumn{2}{|c|}{82} & \multicolumn{2}{|c|}{94} & 176 \\
\hline
\end{tabular}

Source: Research data. ${ }^{\dagger}$ Numeric data equal to zero.

In relation to the sample, we did not observe atypical, inconsistent or unexpected records, on the basis of the obligation to reply to all questions. With the intention of choosing the appropriate statistical methods to be used for data analysis, the normality of the sample was verified through the Kolmogorov-Smirnov test. The data in the present study did not follow a normal, uni or multivariate distribution. On the other hand, in studies with large samples, the negative effects of non-normality tend to be less harmful (HAIR JR. et al., 2005). We therefore considered, the characteristic of non-normality of the sample to choose 
the method of estimation of the parameters with the Structural Equations Modeling Based on Covariance (MEE-CB).

Dimensionality analysis is performed to find out if the data set observed is in agreement with the latent factors of the theoretical model (HAIR JR. et al., 2005; MALHOTRA 2010). We performed an Exploratory Factor Analysis on each theoretical construct, in order to verify the reliability of the variables to each of their respective constructs. The Strategic Planning was the only construct to present a total of explained variance lower than $60 \%$. In this construct, the items with low commonality were removed, that is, excluding the variables III.1 and III.3. The Exploratory Factor Analysis pointed to two eigenvalues greater than 1 for the Focus on the Workforce, which caused it to be divided into two groups, by observing the factor coefficients for its variables, and so the items VI.1, VI.2, VI.6, VI.7 and VI.8 were agglomerated in a sub-item entitled "Stability and Trust", while the variables VI.3, VI.4, VI.5 and VI.9, were grouped under sub-item "Training and Feedback" (KENNY and MACCOACH, 2003). The sub-items were created based on the content expressed in the affirmations, with the indicators of the sub-item being elements contained in the Focus on the Workforce construct.

The reliability of the variables was first verified in relation to the Cronbach's alpha, who measures the proportion of the total variance of the scale, which is attributed to the true score of the latent construct. Acceptable values should be greater than 0.7 (MALHOTRA, 2010). As determined, the Cronbach's alpha of all variables had a value greater than 0.7. According to Hair et al. (2005), it is still necessary to analyze the composite reliability and the mean variance extracted (that is, the convergent validity), of the variables together, and the values of the composite reliability should be greater than 0.7 and should also be greater than the values found for the mean variance extracted, which, in order to be accepted, must be greater than 0.5 ; which occurred for most constructs. The exception observed was in sub-item "Stability and Trust", which was excluded from the analysis, since the mean variance extracted was lower than the suggested value. Therefore, from now on, the Focus on the Workforce construct is now referred to as Focus on Training and Feedback.

The convergent validity analysis also suggests that the Confirmatory Factor Analysis is used as a means of verifying the significance of the relationship of the constructs of interest with the measured indicators (HAIR et al., 2005). The analysis did not indicate any variable with convergent validity problems. However, in the Exploratory Factor Analysis many pairs did not present discriminant validity. Therefore, a method with less conservative characteristics was used to verify the discriminant validity and two Confirmatory Factor Analysis, with each pair of constructs. In the first one, the correlation between the constructs was fixed in 1 and, in the second, the correlation between the constructs was estimated freely. If the chi-square statistic of the model decreases when the correlation between each two factors is freely estimated, there is discriminant validity between this pair, and the difference between the statistics is compared with the chi-square distribution (BAGOZZI, YI and PHILIPS, 1991). The results demonstrated the existence of discriminant validity for all pairs of constructs, thus proving that the variables measure different aspects of the phenomena of interest.

\section{THEORETICAL MODEL AND PROPOSED ALTERNATIVE MODEL}

The analysis of the measurement model was carried out and we confirmed the reliability, convergent validity and discriminant validity of the variables and constructs, the analysis of the structural model was performed through MEE-CB, once it facilitates the discovery and confirmation of relationships between multiple variables (BARRET, 2007; HAIR JR.et al. 2005; GABRIEL and PATEL, 2014) using the AMOS 21 software (BYRNE, 2010; 
ARBUCKLE, 2012). To verify the adjustment of the structural models, we used measures of absolute, incremental and parsimonious adjustments (HAIR JR. et al. 2005; YUAN, 2005; KLINE, 2011).

\subsection{THEORETICAL MODEL}

The greater or lower quality of a model is measured by matching the input data matrix, real or observed (covariance or correlation), with that predicted by the model (HAIR et al., 2005). The summary of the hypothetical model shows that Strategic Planning and Focus on Operation directly influence the Management Effectiveness, which allows us to accept hypotheses $\mathrm{H} 2$ and H6. The results are shown in Figure 3.

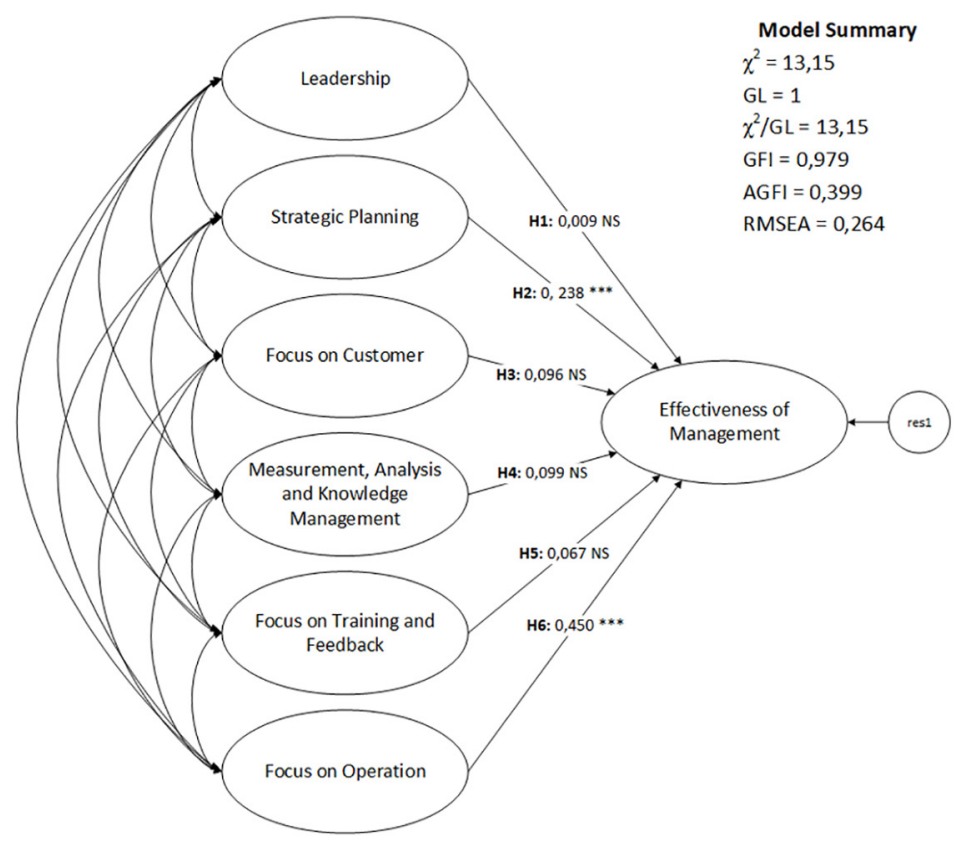

Figure 3. Theoretical Model.

${ }^{\dagger} \mathrm{NS}=$ not significant $|* * * \mathrm{p}<0.01|^{* *} \mathrm{p}<\left.0.05\right|^{*} \mathrm{p}<0.10$

Source: Research data.

However, hypotheses H1, H3, H4 and H5 are rejected because the relations are not statistically significant. That is, we do not observe direct influence of the constructs Leadership; Focus on Customer; Measurement, Analysis and Knowledge Management; and Focus on Training and Feedback, when correlated in the Construct Management Effectiveness. The regression coefficients for the theoretical model are presented in Table 3. 
Table 3. Regression Coefficients of Theoretical Model

\begin{tabular}{|c|c|c|c|c|c|}
\hline Dependent & Independent & Estimate & $\begin{array}{c}\text { Standard } \\
\text { Error }\end{array}$ & Value-p & $\begin{array}{l}\text { Critical } \\
\text { Reason }\end{array}$ \\
\hline \multirow{6}{*}{$\begin{array}{l}\text { Management } \\
\text { Effectiveness }\end{array}$} & Leadership & 0.009 & 0.058 & $0.870 \mathrm{NS}$ & 0.010 \\
\hline & Strategic Planning & 0.238 & 0.065 & $0.000 * * *$ & 0.210 \\
\hline & Focus on Customer & 0.096 & 0.063 & $0.127 \mathrm{NS}$ & 0.090 \\
\hline & $\begin{array}{l}\text { Measurement, Analysis and } \\
\text { Knowledge Management }\end{array}$ & 0.099 & 0.069 & $0.148 \mathrm{NS}$ & 0.100 \\
\hline & $\begin{array}{c}\text { Focus on Training and } \\
\text { Feedback }\end{array}$ & 0.067 & 0.048 & $0.164 \mathrm{NS}$ & 0.080 \\
\hline & Focus on Operation & 0.450 & 0.066 & $0.000 * * *$ & 0.470 \\
\hline
\end{tabular}

$\mathrm{NS}=$ not significant $|* * * \mathrm{p}<0.01| * * \mathrm{p}<0.05 \mid * \mathrm{p}<0.10$

Source: Research data.

Considering the low quality of adjustment of the theoretical model, two of the six hypotheses tested not rejected, which are: the Strategic Planning positively influences the HEI's Management Effectiveness $(\mathrm{H} 2 ; 0.238 ; \mathrm{p}<0.01)$ and the Focus on Operation positively influences the HEI's Management Effectiveness (H6; 0.450; $<<0.01)$. As for the evaluation of the hypothesis $\mathrm{H} 7$, it was only possible to consider with the alternative model proposed below.

\subsection{ALTERNATIVE MODEL}

In social surveys it is good practice to observe the fit of each construct and its respective items, individually in relation to the model, to determine which ones are weakly associated with the variable. Items that have multiple correlation lower than 0.2 can be removed from the model, since they usually have a fairly high error level. In addition, each factor could be modeled in relation to the other factors to find possible relationships between them that were not initially predicted (HAIR JR. et al., 2005).

After the analysis of the correlations between the constructs, we proposed an alternative model, in order to verify hypothesis H7. To determine the relationships in the alternative model, we first considered the confirmation of the hypotheses $\mathrm{H} 2$ and $\mathrm{H} 6$ on the theoretical model that pointed out to Management Effectiveness, a direct influence of the Strategic Planning and Focus on Operation and thus, we understood that these would be mediators of the other constructs, that is, dependent second order variables. Secondly, the other constructs as a function of the relationships visualized in Figure 1, therefore, were positioned as independent first order variables. That is, the Leadership and Customer Focus constructs, when mediated by Strategic Planning; and the Constructs Measurement, Analysis and Knowledge Management and Focus on Training and Feedback, when mediated by Focus Operation, influence Management Effectiveness, that is, the dependent third-order variable. The alternative model and results are presented in Figure 4. 
BBR

15,1

61

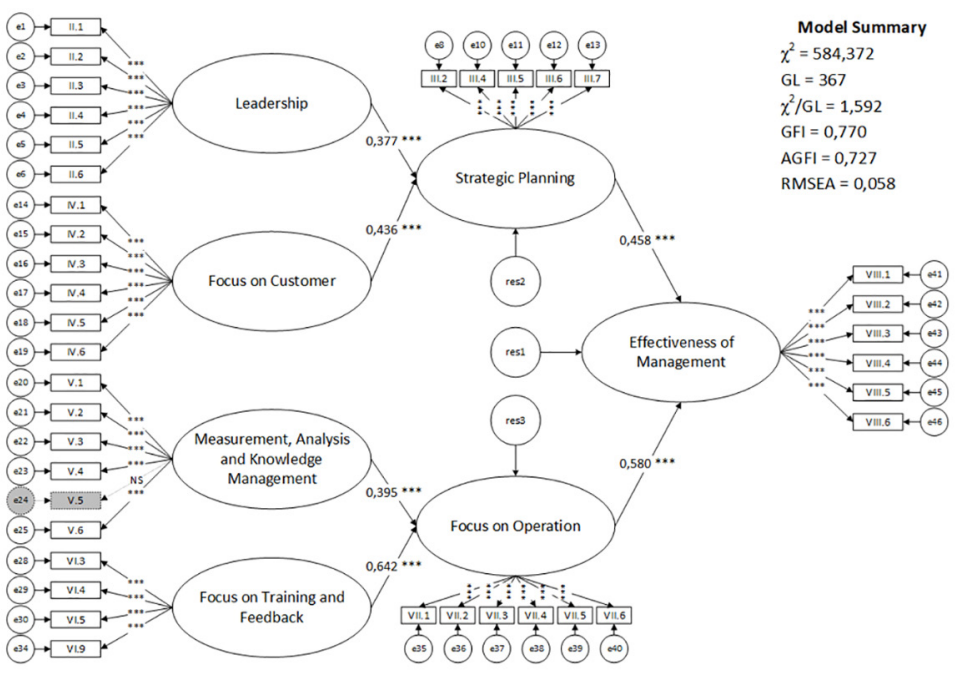

Figure 4. Alternative Model.

${ }^{\dagger} \mathrm{NS}=$ not significant $|* * * \mathrm{p}<0,01| * * \mathrm{p}<0.05 \mid * \mathrm{p}<0.10$

Source: Research data.

About the alternative model, we verified the existence of statistically significant relationships and only the variable V.5 was excluded from the final model, considering that this indicator does not present a significant factor loadings. The regression coefficients for the alternative model are presented in Table 4.

Table 4. Regression Coefficients of the Alternative Model

\begin{tabular}{|c|c|c|c|c|c|}
\hline Dependent & Independent & Estimate & $\begin{array}{l}\text { Standard } \\
\text { Error }\end{array}$ & Value-p & Critical Reason \\
\hline Strategic Planning & Leadership & 0.377 & 0.108 & $* * *$ & 0.377 \\
\hline Strategic Planning & Focus on Customer & 0.436 & 0.084 & $* * *$ & 0.557 \\
\hline Focus on Operation & $\begin{array}{c}\text { Measurement, Analysis } \\
\text { and Knowledge } \\
\text { Management }\end{array}$ & 0.395 & 0.107 & $* * *$ & 0.363 \\
\hline Focus on Operation & $\begin{array}{c}\text { Focus on Training and } \\
\text { Feedback }\end{array}$ & 0.642 & 0.116 & $* * *$ & 0.595 \\
\hline Management Effectiveness & Strategic Planning & 0.458 & 0.068 & $* * *$ & 0.417 \\
\hline Management Effectiveness & Focus on Operation & 0.580 & 0.067 & $* * *$ & 0.581 \\
\hline
\end{tabular}

$\overline{\mathrm{NS}}=$ not significant $|* * * \mathrm{p}<0,01|^{* *} \mathrm{p}<\left.0.05\right|^{*} \mathrm{p}<0.10$

Source: Research data.

Finally, we observe in Figure 4 that the alternative model summary presents better fit quality indicators, when compared to those obtained in the theoretical model. Therefore, the validity of the alternative model on the $\mathrm{H} 7$ hypothesis in this study is demonstrated, when verifying the existence of partial correlation between the constructs in the alternative model with the HEI's Management Effectiveness. Specifically, Leadership and Focus on Customer on the Strategic Planning; Measurement, Analysis and Knowledge Management and Focus on the Workforce with Focus on Operations; and Strategic Planning and Focus on Operations with Management Effectiveness. The respective quality adjustment indices of the models (KLINE, 2011) are shown in Table 5. 
Table 5. Theoretical Model versus Alternative Model

\begin{tabular}{|c|c|c|c|c|}
\hline Measure & Fit Index & $\begin{array}{l}\text { Theoretical } \\
\text { Model }\end{array}$ & $\begin{array}{l}\text { Alternative } \\
\text { Model }\end{array}$ & Reference Parameters ${ }^{\mathrm{a}}$ \\
\hline \multirow{8}{*}{ 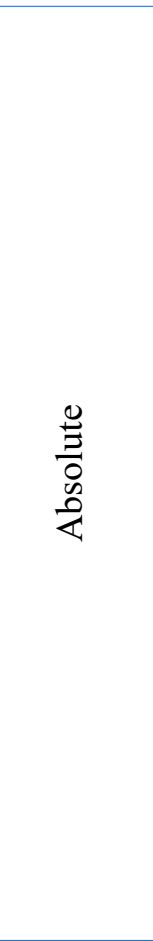 } & Chi-square $(\chi 2)$ & 13.150 & 584.372 & \multirow{3}{*}{ Not applicable } \\
\hline & $\begin{array}{l}\text { Degrees of freedom } \\
\text { (DF) }\end{array}$ & 1 & 367 & \\
\hline & $\begin{array}{l}\text { Significance of the Mo- } \\
\text { del (Value-p) }\end{array}$ & $\mathrm{p}<0.01$ & $\mathrm{p}<0.01$ & \\
\hline & $\begin{array}{l}\text { Root Mean Square } \\
\text { Error of Approximation } \\
\text { (RMSEA) }\end{array}$ & 0.264 & 0.058 & $\begin{array}{l}\text { Great.... : RMSEA }<0.060 \\
\text { Good : } 0,060 \leq \text { RMSEA }< \\
0.080 \\
\text { Average. : } 0,080 \leq \text { RMSEA }< \\
\text { 0.100 } \\
\text { Unsuitable. : RMSEA }>0.100 .\end{array}$ \\
\hline & $\begin{array}{l}\text { Goodness of Fit Index } \\
\text { (GFI) }\end{array}$ & 0.979 & 0.770 & \multirow{2}{*}{$\begin{array}{l}\text { Great. : } 1<\text { GFI or AGFI } \leq 0.95 \\
\text { Good. : } 0.95<\text { GFI or AGFI } \leq 0.90\end{array}$} \\
\hline & $\begin{array}{l}\text { Adjusted Goodness of } \\
\text { Fit Index (AGFI) }\end{array}$ & 0.399 & 0.727 & \\
\hline & $\begin{array}{l}\text { Confidence Interval } \\
(90 \%) \text { for RMSEA }\end{array}$ & {$[0.150 ; 0.398]$} & {$[0.049 ; 0.067]$} & Not applicable \\
\hline & $\begin{array}{c}\text { Standardized Root } \\
\text { Mean Square Residual } \\
\text { (SRMR) }\end{array}$ & 0.012 & 0.090 & $\begin{array}{l}\text { Suitable..... : SRMR } \leq 0.09 \\
\text { Unsuitable..... : SRMR }>0.09\end{array}$ \\
\hline 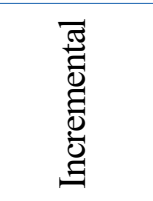 & $\begin{array}{l}\text { Comparative Fit Index } \\
\qquad(\mathrm{CFI})\end{array}$ & 0.878 & 0.831 & $\begin{array}{l}\text { Great..... : CFI } \geq 0.95 \\
\text { Good....: }: 0,90 \leq \mathrm{CFI}<0.95 \\
\text { Average }: 0.80 \leq \mathrm{CFI}<0.90 \\
\text { Unsuitable }: \text { CFI }<0.80\end{array}$ \\
\hline \multirow{2}{*}{ 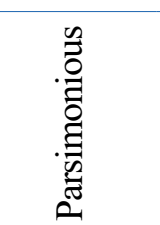 } & $\begin{array}{l}\text { Parsimony Normalized } \\
\text { Fit Index (PNFI) }\end{array}$ & 0.042 & 0.207 & The bigger the better \\
\hline & $\begin{array}{l}\text { Scaled Chi-square }\left(\chi^{2} /\right. \\
\text { DF })\end{array}$ & 13.150 & 1.592 & $\begin{array}{l}\text { Suitable: } 1,000<\chi^{2} / \mathrm{GL} \leq 3,000 \\
\text { Unsuitable... : } \chi^{2} / \mathrm{GL}>3,000\end{array}$ \\
\hline
\end{tabular}

Source: Research data. ${ }^{\dagger}$ a) Adapted from Golden Rules (KLINE, 2011).

\subsection{RESULTS ANALYSIS}

Once the theoretical model is described, a simultaneous, partial, positive and different size correlation is observed between some of the constructs from the Baldrige Excellence Criteria, when we verify that the HEI's Management Effectiveness is influenced by the Strategic Planning and Focus on Operation. In turn, the alternative model demonstrates that the Leadership and Focus on Customer constructs, mediated by Strategic Planning; and the Measurement, Analysis, and Knowledge Management and Focus on the Workforce constructs, mediated by Focus on Operation, influence the HEI's Management effectiveness. In this sense, the following interpretations are derived from hypothesis $\mathrm{H} 7$ on the alternative model: "There is a correlation between the constructs of the model and the HEI's Management Effectiveness".

Strategic Planning was positively related to $(0,458 ; p<0,01)$ the HEI's Management Effectiveness. From the perspective of the Baldrige Excellence Model, the internal and external environments of the organization must be analyzed (BPEP, 2011). This means realizing that the relationship of strategy to leadership and focus on customer, particularly when strategic planning is influenced by the last two, should be seen as the possibility of 
BBR

15,1

63

achieving the results that are on the definition of goals and objectives of the HEI, because this implies the way in which the direction, when considering the reach of the results, leads the work teams, professors and the administrative staff, in addition to communicating with customers, students, shareholders, among other stakeholders. In fact, it is demonstrated that strategic planning is a tool to support decision making (KICH and PEREIRA, 2011), with this, we can understand it as a way for the organization to prepare for the future.

It was evidenced that the constructs Leadership $(0.377 ; \mathrm{p}<0.01)$ and Focus on Customer $(0.436 ; p<0.01)$ are positively related to Strategic Planning. An interpretation derived from these relationships is that the type of leadership, as described by Rocha, Cavalcanti and Souza (2010, p. 36), means that "leading corresponds to a process of intentionally influencing an individual in order to achieve a goal", which in this case is associated with the student of the HEI, that is, it justifies Focus on Customer. These results point out that there is a greater concern in the HEI with the levels of student satisfaction, when considering the existence of other competitors, as well as the segmentation and attention given to complaints, suggestions and expectations that emerge as a way of responding quickly to internal demands, interfering with the level of student satisfaction and retention.

Focus on Operation was positively related $(0.580 ; p<0.01)$ to the HEI's Management Effectiveness. From the perspective of the Baldrige Excellence Model, special attention should be given not only to the strategy formulation process, but to the strategy itself in action (BPEP, 2011). Thus, the educational operations, contextualized as the accomplishment of the tasks associated with teaching, the educational, administrative and financial processes, besides the possibility of reversing functional frameworks, when unforeseen situations occur, it indicates in the HEI a concern of the direction with the work teams, and administrative staff, because they are responsible for making the strategy come true, within the action plans established by the management. This is corroborated by Kich and Pereira (2011), by stating that the operationalization of the strategy, as a way of achieving the objectives outlined is more important than the strategic planning process itself.

The Constructs Measurement, Analysis and Knowledge Management $(0.395 ; p<0.01)$ and Focus on Training and Feedback $(0.642 ; \mathrm{p}<0.01)$ are positively related to Focus on Operation. This last value means that Focus on Training and Feedback is the most important aspect for the achievement of educational operations at the HEI, which suggests managerial attention to the aspects related to the qualification and performance of the work teams, as an efficient allocation and creation of high performance teams, when thinking about the achievement of results. These, in turn, require measurement, analysis and knowledge management, as suggested by Georges (2010), by pointing out that organizations need information systems that are able to collect, store and process information with the intention of sustaining the organization's decision-making and control, with speed and effectiveness. This implies the need to correctly choose the information technology solutions that are used in the HEI, besides providing the administrative and teaching staff with adequate conditions for the use of computerized solutions through training and qualification.

\section{FINAL CONSIDERATIONS}

The objective of this study is to analyze the antecedents of management effectiveness of higher education of a Brazilian HEI according to the Baldrige Excellence Model. The results indicate that the Strategic Planning and the Focus on Operation are relevant for the HEI's Management Effectiveness. Strategic Planning is an important tool for decisionmaking (WHEATON et al., 1997; KICH and PEREIRA, 2011; SOUZA 2011). However, the ways of implementing the strategy to reach the goals becomes more important for the Management Effectiveness, given that the Focus on Operations dimension is more valued by those who put the strategy into action in the educational environment (BARRETO and 
POZO, 2011; BPEP, 2011; KICH and PEREIRA, 2011; MAINARDES, MIRANDA and CORREIA, 2011).

The Constructs Leadership; Focus on Customer; Measurement, Analysis and Knowledge

Management; and Focus on Training and Feedback have no direct influence on the HEI's Management Effectiveness, however they relate and contribute to the HEI's Management Effectiveness, since they are seen as antecedents of the constructs Strategic Planning and Focus on Operation, which have a direct influence on the HEI's Management Effectiveness; therefore these constructs allow new research agendas on the theme of organizational effectiveness. It has also been shown that Leadership, as the act of intentionally influencing people in pursuit of specific results, as well as the students' perception of quality, described by the Focus on Customer, are important elements and should be considered in the preparation of the Strategic Planning of a HEI (ROCHA, CAVALCANTE and SOUZA, 2010; BPEP, 2011). Finally, in order for the strategy to take action, contemplated in educational operations, measurement, analysis and management of knowledge has an important role in capturing, organizing and supporting decision-making through the organization of information systems (GEORGES, 2010; BPEP, 2011), but it can only become more relevant if actions are built and directed towards training and feedback from the workforce.

This research contributes to the academic and practical perspective, from the observation that the Strategic Planning, as an organizational decision-making tool and the Focus on Operations, as a distinct action of planning that puts the strategy into action, they are the most representative elements to the HEI's Management Effectiveness, since the direct influence is observed, especially when one considers that the case study was carried out in a company which operates in the open capital model, whose management processes throughout the organization are focused on profit and aim to meet the financial expectations of shareholders and stakeholders. Specifically, in relation to the theory, there is an advance in the sense of empirically testing the Baldrige Excellence Model, to the point that the previous study by Galvão, Corrêa and Alves (2011) indicated that this model is adequate to the reality of Brazilian HEIs.

In addition, from the methodological perspective, we demonstrate that the Baldrige Excellence Model needs to be contextualized to the characteristics of Brazilian HEIs, especially when in a private HEI, the alternative model was pointed out. From the pragmatic point of view, the work contributes to the management of HEI and institutional evaluation, when it demonstrates in the strategic perspective with focus on the results that the actions of the direction must focus on the interested parties, internal or external, to provide economic returns to shareholders, because the educational operations and the satisfaction and retention of students are associated with the training and qualification of the administrative and teaching staff in the HEI.

The main limitation of the study is the fact of testing two distinct models, however it is pointed out that the alternative model has a better quality of adjustment over the research data. This aspect, which may at first sight be seen as a limitation, signals to other researchers the possibility and necessity of seeking alternative paths, without, however, loosing methodological consistency, so limitation is reported as a potentiality to be considered in scientific investigations. Therefore, the research demonstrates results relevant to the context of a Brazilian HEI, because it allows analyzes derived from the literature on the Baldrige Excellence Criteria and Effectiveness (MELO and NETO, 2009; BPEP, 2011; GALVÃO, CORREAA and ALVES, 2011; SARAIVA and NUNES, 2011; SOUZA, 2011), which in fact contribute to the management of the Institution of Higher Education, in addition to meeting the obligations for education that are provided for in Law in Brazil (BRASIL, 2008; SILVA JÚNIOR, MUNIZ and MARTINS, 2009).

As a suggestion for future research, we believe that the study can be carried out in other metropolitan regions of Brazil, with the intention of investigating different regional 
BBR

15,1

65

perceptions and cultures, including public HEIs. In these, the theoretical model and the alternative model can demonstrate how the organizational effectiveness is seen from the perspective of the public sector, which would also allow the comparison of the results obtained through the Baldrige Excellence Model between private HEIs and public HEIs. We also suggest the application of the contextualized model to companies to analyze how the graduates of HEI contribute to the results of organizations, due to the fact that they absorb the labor force formed by the private or public HEI and, with this, measure management effectiveness on the perception of other actors in the educational process, which can somehow contribute to the decision making within HEIs.

\section{CONTRIBUTION OF AUTHORS}

There are no conflicts of interest. The article is the result of the research developed as a partial requirement to obtain the degree of Master in Administration of the author Paulo Henrique Barroso Menezes under the guidance of the author Prof. PhD. Henrique Cordeiro Martins at the University FUMEC. The author Ronielton Rezende Oliveira under the guidance of Prof. PhD. Henrique Cordeiro Martins in the Doctoral Degree in Administration at the University FUMEC and contributed by reviewing the models, analyzing the data and discussing the results of the research, preparing and reviewing the article for submission, after presenting the work in the Annals of XXXIX National Meeting of the National Association of Graduate Studies and Research in Administration (EnANPAD 2015).

\section{REFERENCES}

ARBUCKLE, J. L. IBM SPSS Amos 21 User's Guide. New York: IBM, 2012.

BAGOZZI, R. P.; YI, Y.; PHILIPS, L. W. Assessing construct validity in organizational research. Administrative Science Quarterly, v. 36, n. 3, p. 421-458, 1991.

BARBOSA, M. A. C.; MENDONÇA, J. R. C.; CASSUNDE, F. R. S. A. A Interação entre o Papel de Professor-Gestor e Competências Gerenciais: percepções dos professores de uma Universidade Federal. In: COLÓQUIO INTERNACIONAL DE GESTÃO UNIVERSITÁRIA, 15., 2015, Mar del Plata. Anais...Florianópolis: UFSC, 2015.

BARRET, P. Structural equation modelling: adjudging model fit. Personality and individual Differences, v. 42, n. 5, p. 811-898, 2007.

BARRETO, A. F.; POZO, H. A flexibilidade organizacional como fator estratégico para a obtenção de vantagem competitiva: um estudo nas pequenas indústrias metalúrgicas da região de Osasco. Revista Gestão \& Regionalidade, v. 27, n. 80, p. 97-110, 2011.

BERTUCCI, J. L. O.; DE MORAES, W. B. Efetividade organizacional na perspectiva de coordenadores de cursos de graduação da PUC Minas. Revista Economia \& Gestão, v. 3, n. 6, p. 58-89, 2003.

BPEP. BALDRIGE PERFORMANCE EXCELLENCE PROGRAM (EUA). Criteria for Performance Excellence. Gaithersburg, MD, 2011. 88p.

BRANDALISE, M. A. T. Avaliação institucional da escola: conceitos, contextos e práticas. Olhar de Professor, v. 13, n. 2, p. 317-332, 2010.

BRASIL, Constituição. Constituição da República Federativa do Brasil, 1988.

BRUCKMANN, S.; CARVALHO, T. The reform process of Portuguese Higher Education Institutions. From collegial to managerial governance? Tertiary Education and Management, v. 20, n. 3, p. 193-206, 2014.

BYRNE, B. M. Structural equation modeling with AMOS: Basic concepts, applications, and programming. 2nd ed. New York: Routledge, 2010.

CAMERON, K. Domains of organizational effectiveness in colleges and universities. Academy of Management Journal, v. 24, n. 1, p. 25-47, 1981.

CAMERON, K. Measuring organizational effectiveness in institutions on higher education. Administrative Science Quarterly, v. 23, p. 604-31, 1978.

CLAUDIA, S., VEIGA, A.; AMARAL, A. The long road - how evolving institutional governance mechanisms are changing the face of quality in Portuguese higher education. Educational Assessment, Evaluation and Accountability, v. 25, n. 4, p. 375-391, 2013. 
DARAIO, C. Efficiency, Effectiveness and Impact of Research and Innovation. Where is education? In: Consortium of High Education Research, 28., 2015, Lisbon. Anais... Lisbon: CHER, 2015.

DONINA, D.; BRUCKMANN, S. Convergence or Divergence in university institutional governance reforms? Comparing Napoleonic states. In: Consortium of High Education Research, 28., 2015, Lisbon. Anais...Lisbon: CHER, 2015

FERNANDES, M. N.; BARALE, R. F.; SANTOS, T. R. C.; COSTA, T. P. A.; GOMIDE JÚNIOR, S. Percepção de efetividade organizacional: construção e validação de uma medida do construto. Revista Psicologia Organizações e Trabalho, v. 7, n. 2, p. 115-132, 2007.

FIDELIS, J. R. F.; BARBOSA, R. R. A competência informacional e sua influência na percepção de variáveis organizacionais estratégicas em IES Privadas. Perspectivas em Gestão \& Conhecimento, v. 2, n. Especial, p. 27-39, 2012.

FREITAS JÚNIOR, O. G.; BARROS, P. A. M.; BARBIRATO, J. C. C.; BRAGA, M. M.; CARVALHO, V. D. H. Reestruturando o modelo de Universidade Pública Brasileira para atender aos novos desafios gerenciais. In: COLÓQUIO INTERNACIONAL DE GESTÃO UNIVERSITÁRIA, 15., 2015, Mar del Plata. Anais... Florianópolis: UFSC, 2015.

GALVÃO, H. M.; CORRÊA, H. L.; ALVES, J. L. Modelo de avaliação de desempenho global para instituição de ensino superior. Revista de Administração da UFSM, v. 4, n. 3, p. 425-441, 2011.

GEORGES, M. R. R. Modelagem dos processos de negócios e especificação de um sistema de controle da produção na indústria de autoadesivos. Revista de Gestão da Tecnologia e Sistemas de Informação, v. 7, n. 3, p. 639-668,2010.

HAIR JR., J. F., GABRIEL, M., PATEL, V. AMOS Covariance-Based Structural Equation Modeling (CBSEM): Guidelines on its Application as a Marketing Research Tool. Revista Brasileira de Marketing, v. 3, n. 2., p. 44-55, 2014.

HAIR JR., J. F.; BABIN, B.; MONEY, A. H.; SAMOUEL, P. Fundamentos de Métodos de Pesquisa em Administração. Porto Alegre: Bookman, 2005.

HALLIGAN, J., SARRICO, C. S.; RHODES, M. L. On the road to performance governance in the public domain? International Journal of Productivity and Performance Management, v. 61, n. 3, p. 224-234, 2012.

INEP. INSTITUTO NACIONAL DE ESTUDOS E PESQUISAS EDUCACIONAIS ANÍSIO TEIXEIRA. Sinopses Estatísticas da Educação Superior - Graduação, 2014. Disponível em: http://portal.inep.gov. br/superior-censosuperior-sinopse.Accesso em: 01.07.2016.

KENNY, D. A.; MCCOACH, D. B. Effect of the Number of Variables on Measures of Fit in Structural Equation Modeling. StructuralEquationModeling: A Multidisciplinary Journal, v. 10, n. 3, p. 333351, 2003.

KICK, J. I. D. F.; PEREIRA, M. F. A influência da liderança, cultura, estrutura e comunicação organizacional no processo de implantação do planejamento estratégico. Cadernos EBAPE.BR, v. 9, n. 4, p. 1046-1065, 2011.

KLINE, R. B. Principles and Practice of Structural Equation Modeling. 3rd ed. New York: Guilford Publications, 2011.

MAGAlHÃES, A., VEIGA, A., RIBEIRO, F.; AMARAL, A. Governance and Institutional Autonomy: Governing and Governance in Portuguese Higher Education. Higher Education Policy, v. 26, n. 2, p. 243-262, 2013.

MAGALHÃES, A.; VEIGA, A. Leadership and Governance in Higher Education: handbook for decisionmakers and administrators. Berlin: RaabeAcademicPublishers, 2014.

MAINARDES, E. W; MIRANDA, C. S.; CORREIA, C. H. A gestão estratégica de instituições de ensino superior: um estudo multicaso. Contextus - Revista Contemporânea de Economia e Gestão, v. 9, n. 1, p. 19-31, 2011.

MALHOTRA, N. Pesquisa de Marketing:uma orientação aplicada. Porto Alegre: Bookman, 2010.

MELO, R. P.; S. NETO, J. M. Avaliação Qualificada de Resultados: A Presença dos Conceitos de Efetividade, Eficácia e Eficiência na Gestão do Plano Plurianual 2004/2007. In: ENCONTRO DA ASSOCIAÇÃO NACIONAL DE PÓS-GRADUAÇÃO E PESQUISA EM ADMINISTRAÇÃO, 33. 2009, São Paulo. Anais... Rio de Janeiro: ANPAD, 2009.

MORALES, R; MAGALHÃES, A. Visiones, tensiones y resultados. La nueva gobernanza de la educación. Archivos Analíticos de Políticas Educativas, v. 21, n. 3, p. 1-13, 2013.

PAIVA, R. V. C.; COSTA, D. M.; GONÇALVES, R. G.; DIAS, A. T. Educação Superior Privada no Brasil: uma análise da avaliação de desempenho de nove instituições de ensino segundo o método 
BBR

15,1

67

Economic Value Added. In: COLÓQUIO INTERNACIONAL DE GESTÃO UNIVERSITÁRIA, 14. 2014, Florianópolis. Anais... Florianópolis: UFSC, 2014.

PALMEIRAS, J. B.; SGARI, R.; SZILAGYI, C. L. S. Desafios da Gestão Universitária: competência e desempenho, uma reflexão crítica na gestão. In: COLÓQUIO INTERNACIONAL DE GESTÃO UNIVERSITÁRIA, 15., 2015, Mar del Plata. Anais... Florianópolis: UFSC, 2015.

ROCHA, D.; CAVALCANTE, C. E.; SOUZA, W. J. Estilos de Liderança: Estudo de Caso em uma Organização Militar. Revista de Administração da UNIMEP, v. 8, n. 2, p. 35-50, 2010.

ROSA, P. C.; SANTOS, N. M. B. F.; SANTOS, R. F. Desempenho de Processos Educacionais Mensuração e Aplicação em Instituições de Ensino Superior. In: COLÓQUIO INTERNACIONAL DE GESTÃO UNIVERSITÁRIA NA AMÉRICA DO SUL, 6., 2006, Blumenau. Anais... Florianópolis: UFSC, 2006.

SARAIVA, L. A. S.; NUNES, A. S. A efetividade de programas sociais de acesso à educação superior: o caso do ProUni. Revista de Administração Pública, v. 45, n. 4, p. 941-964, 2011.

SARRICO, C. S., VEIGA, A.; AMARAL, A. Quality, Management and Governance in European Higher Education Institutions. Journal of the European Higher Education Area, v. 4, pp. 47-70, 2013.

SILVA JÚNIOR, A.; MUNIZ, R. M.; MARTINS, P. O. Governança corporativa na IES familiar de grande porte: um estudo de caso. Revista Alcance, v. 16, n. 3, p. 286-303, 2009.

SOBRAL, F. J. B. A.; GIMBA, R. F. As prioridades axiológicas do líder autêntico: um estudo sobre valores e liderança. Revista de Administração Mackenzie, São Paulo, v. 13, n. 3, p. 96-121, 2012.

SOUZA, C. M. L. Entre o planejamento estratégico formal e informal: um estudo de caso exploratório sobre a prática de estratégia nas organizações. Revista de Administração Contemporânea, v. 15, n. 5, p. 855876, 2011.

SOUZA, H. A.; BEZERRA, M. J. S. Gestão Educacional: um instrumento de avaliação para o segmento educação. In: COLÓQUIO INTERNACIONAL DE GESTÃO UNIVERSITÁRIA NA AMÉRICA DO SUL, 4., 2004, Florianópolis. Anais... Florianópolis: UFSC, 2004.

TELLES, R.; MARINHO, S. V. Avaliação do Desempenho Docente em Instituições de Ensino Superior. In: COLOQUIO DE GESTIÓN UNIVERSITARIA EN AMÉRICAS, 13., 2013, Buenos Aires. Anais... Florianópolis: UFSC, 2013.

VIDIGAL, F.; CAMPOS, L. W. Do Planejamento Estratégico à Prática de Gestão na Universidade Pública: um estudo na UFG. In: COLÓQUIO INTERNACIONAL DE GESTÃO UNIVERSITÁRIA, 15., 2015, Mar del Plata. Anais...Florianópolis: UFSC, 2015.

WHEATON, B.; MUTHÈN, B.; ALWIN, D. F.; SUMMERS, G. Assessing Reliability and Stability in Panel Models. In: HEISE, D. (Ed). Sociological Methodology. San Francisco: Jossey-Bass, 1977. p. 84-136.

YUAN, K. H. Fit Indices versus Test Statistics. Multivariate Behavioral Research,v. 40, p. 115-148, 2005. ZANIN, A.; POLI, O. L.; MOURA, G. D.; JUNG, C. F.; TEN-CATEN, C. S. Definição de Painel de Indicadores de Desempenho para Instituições Comunitárias de Ensino Superior. In: COLÓQUIO INTERNACIONAL DE GESTÃO UNIVERSITÁRIA, 14., 2014, Florianópolis. Anais... Florianópolis: UFSC, 2014. 